\title{
Use of a 10.22 m diameter EPB shield: a case study in Beijing subway construction
}

\author{
Xinggao $\mathrm{Li}^{i^{*}}$, Dajun Yuan ${ }^{1}$, Yuhai Guo ${ }^{2}$ and Zhiyong Cai ${ }^{2}$
}

\begin{abstract}
Introduction: Beijing subway line 14 includes four stations and approximately $2.8 \mathrm{~km}$ of tunnels between the Dongfengbeiqiao and Jingshunlu areas of the city. Due to the surface and underground space limitations of this section, a double-track running tunnel instead of two single-track running tunnels was adopted to connect the two stations. The double-track tunnels were excavated by a $10.22 \mathrm{~m}$ diameter earth pressure balance (EPB) shield. It was the first time that an EPB shield more than $10 \mathrm{~m}$ in diameter was used in Beijing subway construction.

Case description: The shield, which passes underneath densely built-up areas of the city and is equipped with a spoke-type cutterhead, with balance between the ground pressure and the earth chamber pressure at the tunnel face, is of great importance. Referring to experiences gained in the EPB shield tunneling, attention was paid to the function of soil conditioning and simultaneous backfilling grouting of the shield, and some special designs were considered in manufacturing the machine.

Discussion and Evaluation: In addition to the agitating rods welded to the cutterhead, two independently driven agitators were added to fully mix everything in the earth chamber. Independent pipelines were arranged for injecting different conditioning agents. Indoor tests in combination with field tests were conducted to find suitable additives and injection ratios of the additives, and determine the mix ratio of the two-component grout for simultaneous backfilling grouting. A scheme was employed for simultaneously injecting the bentonite slurry at $8 \%$ concentration and the foam liquid at $5 \%$ concentration to condition the excavated soil. The cement-sodium silicate grout was adopted to fill the tail void and the injection volume per ring was $14.1-15.3 \mathrm{~m}^{3}$.

Conclusions: The performance of the shield and evaluation of the corresponding tunneling technologies are introduced in terms of the shield tunneling induced ground surface settlements. The success of the project is of great significance to Beijing subway construction and underground space utilization. The findings serve as a useful reference for similar projects.
\end{abstract}

Keywords: 10.22 m Diameter EPB shield, Spoke-type cutterhead, Soil conditioning, Simultaneous backfilling grouting

\section{Background}

In the past decade, the subway system has been increased dramatically due to the large population and limited surface spaces in Beijing, which is the capital and one of the most important economic centers of China. For the underground lines in the city, usually subway stations are connected by two running tunnels: one down-line tunnel and one up-line tunnel. Beijing is currently extending

\footnotetext{
*Correspondence: Ixg_njtu@163.com

1 School of Civil Engineering, Beijing Jiaotong University, Beijing 100044, China

Full list of author information is available at the end of the article
}

its subway network, although the underground space of the city is becoming increasingly more scarce, especially at shallow depths. Therefore, sufficient space to accommodate spaced twin single-track running tunnels does not always exist, and constructing a subway station using conventional methods and technologies can't be done smoothly due to restrictions caused by surrounding environment. However, these problems can be effectively addressed when a double-track tunnel is adopted instead of twin single-track running tunnels, where the subway stations are formed by expanding the finished doubletrack tunnel. The construction planning of the project 
is running tunnel construction oriented rather than station construction oriented. Stations can be planned in advance and constructed when necessary. Moreover, in a double-track tunnel, a crossover can be easily realized. Double-track tunnels are constructed using the large diameter earth pressure balanced (EPB) shield tunneling method because of the many advantages it offers over conventional methods. Thus, the smooth and rapid construction of the shield tunnel is of great importance for the on-schedule completion of the project. This is explained by use a $10.22 \mathrm{~m}$ diameter EPB shield to build the double-track tunnels on Line 14 of the Beijing subway.

It was the first time that an EPB shield more than $10 \mathrm{~m}$ in diameter was used in Beijing subway tunnel construction. The main focus was on the equipment required for soil conditioning and simultaneous backfilling grouting of the large diameter EPB shield when designing the shield in the initial stage of the project. During the period of constructing the double-track tunnels, emphasis was placed on determining the key driving parameters, such as earth chamber pressure and advance rate. The shield tunneling was completed as planned. This paper presents the special designs and performance of the EPB shield in terms of the maximum settlements of the ground surface.

\section{Project overview}

The project includes three stations (Dongfengbeiqiao station $298.7 \mathrm{~m}$ in length, Jiangtai station $166 \mathrm{~m}$ in length and Gaojiayuan station $179 \mathrm{~m}$ in length) and approximately $2507.9 \mathrm{~m}$ of double-track tunnels on Beijing subway Line 14, as shown in Fig. 1. Instead of two single-track running tunnels, one double-track running tunnel was adopted to connect two neighboring stations due to the limited surface and underground space. A $10.22 \mathrm{~m}$ diameter EPB shield was chosen, after overall considerations, to excavate the double track tunnels. To reduce the project duration, the construction plan employed involved completing the continued $3151.6 \mathrm{~m}$ long shield driving first, followed by construction of the two stations (Jiangtai and Gaojiayuan stations) by expanding the finished shield tunnel. The enlargement was realized by using a modified PBA method (Liu et al. 2015). The PBA method is a manual excavation method, which is widely used in Beijing to build subway stations.

The soils at the job site can be divided into three groups: (1) backfill; (2) silt and silty clay and (3) fine and medium sand, as shown, taking the running tunnel between Gaojiayuan station and Jingshunlu station as an example, in Fig. 2. The soil group properties are listed in Table 1. There are four types of aquifers involved: (1) perched aquifer, (2) unconfined aquifer, (3) confined aquifer I and (4) confined aquifer II, with water tables of 2.98-6.79, $5.98-9.25,11.70-18.40$ and $21.00-27.65 \mathrm{~m}$ underneath the surface, respectively. The overburden depth ranges from 11.3 to $21.2 \mathrm{~m}$. Two elements concerning the tunnel alignment are the minimum curve radius of $350 \mathrm{~m}$ and the maximum slope of $27 \%$. The soils of sand, rich in ground water, the shallow overburden, and the small curve radius will together contribute to high surface settlement if not properly addressed.

The project was constructed in the densely built-up areas of Beijing. The large diameter shield tunneling influenced the nearby buildings and structures. The

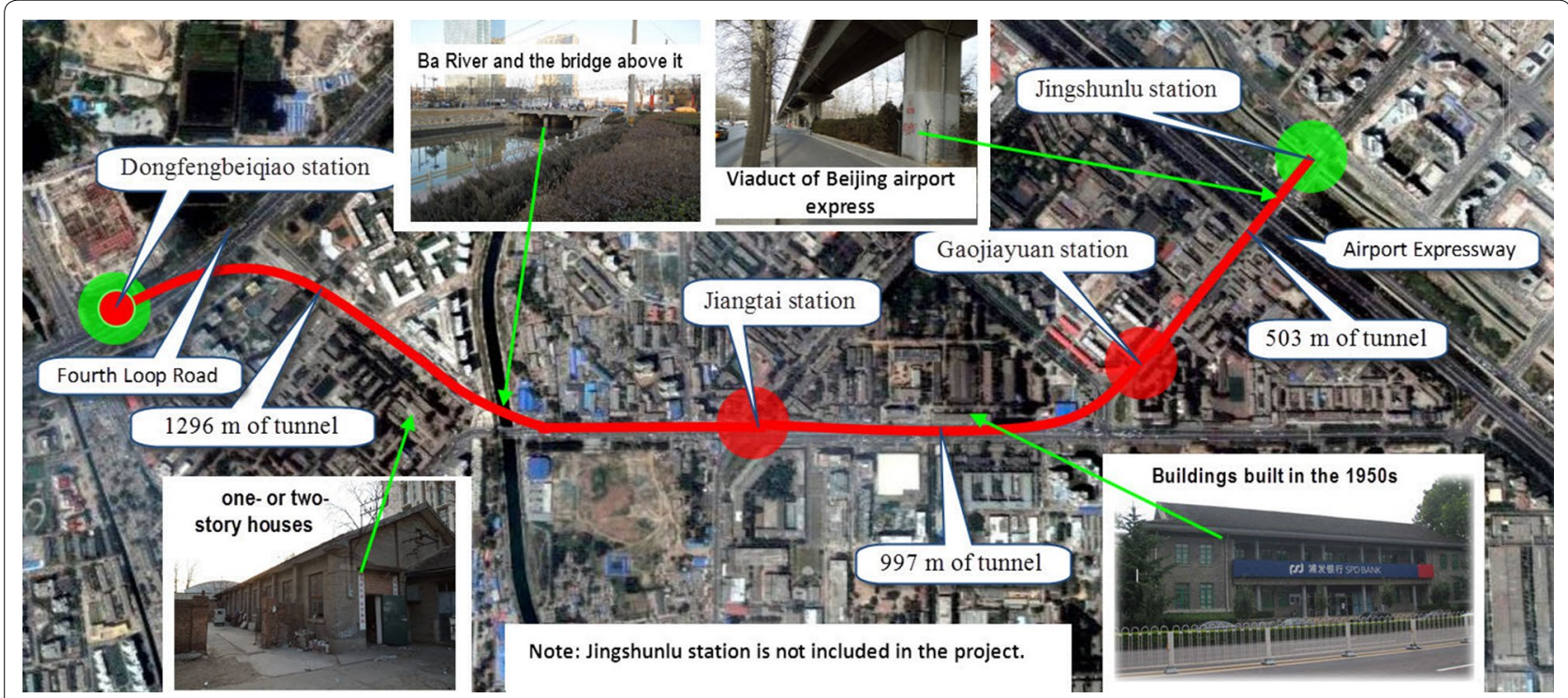

Fig. 1 Beijing subway line 14 route between Dongfengbeiqiao station and Jingshunzhan station 


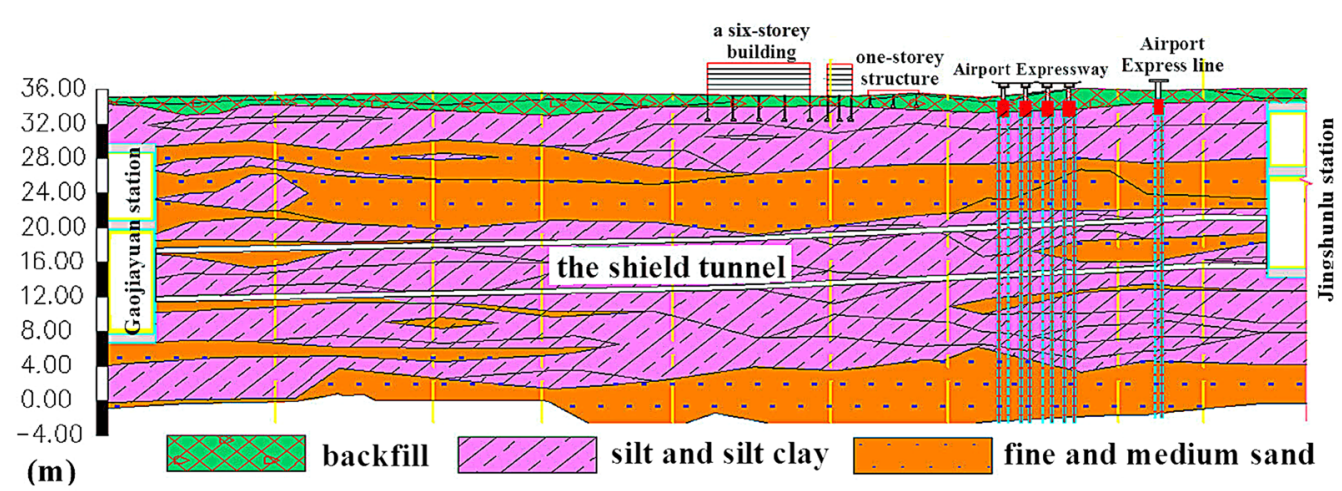

Fig. 2 Longitudinal section between Gaojiayuan station and Jingshunlu station

Table 1 Soil group properties

\begin{tabular}{|c|c|c|c|c|c|c|}
\hline Soil group & Natural density $\left(\mathrm{g} / \mathrm{cm}^{3}\right)$ & Dry density $\left(\mathrm{g} / \mathrm{cm}^{3}\right)$ & Porosity & Liquid limit (\%) & Plastic limit (\%) & SPT N-values \\
\hline Backfill & $1.58-1.65$ & - & - & - & - & - \\
\hline Silt and silty clay & $1.89-2.08$ & $1.43-1.76$ & $0.349-0.476$ & $26.1-40.9$ & $17.6-25.4$ & - \\
\hline Fine and medium sand & $2.02-2.10$ & - & - & - & - & $23-53$ \\
\hline
\end{tabular}

shield drove under the main city roads, so the road surface and buried pipelines along the roads were affected. The involved pipelines include the heat supply, gas, water supply and drainage, cable, communication pipelines and so forth. Other risk sources identified are the numerous one- or two-story houses, the low-rise buildings built in the 1950s, Ba River and the bridge above the river, the Fourth Loop Road, the Airport Expressway and the viaduct of Beijing airport express, under which the shield passes, as shown in Fig. 1. The surroundings were sensitive to the shield tunnel construction, which posed significant challenges to the project.

\section{Selection of shield types and special design of the shield}

\section{Selection of shield types}

The selection between the EPB- and slurry-shields is influenced by three types of factors: economic, technical and geological, and a thorough and detailed discussion is often required. However, the use of an EPB shield in this project can be justified by two reasons: (1) the accumulated experience and skill with the use of the $6.15 \mathrm{~m}$ diameter EPB shields in Beijing area and (2) the lack of sufficient ground surface space for a sophisticated separation plant for the slurry shield. As presented in Fig. 3, the used machine is equipped with a spoke-type cutterhead, with an opening ratio of $65 \%$. Important technical parameters of the shield are summarized in Table 2. In Table 2, the maximum torque coefficient is related to the

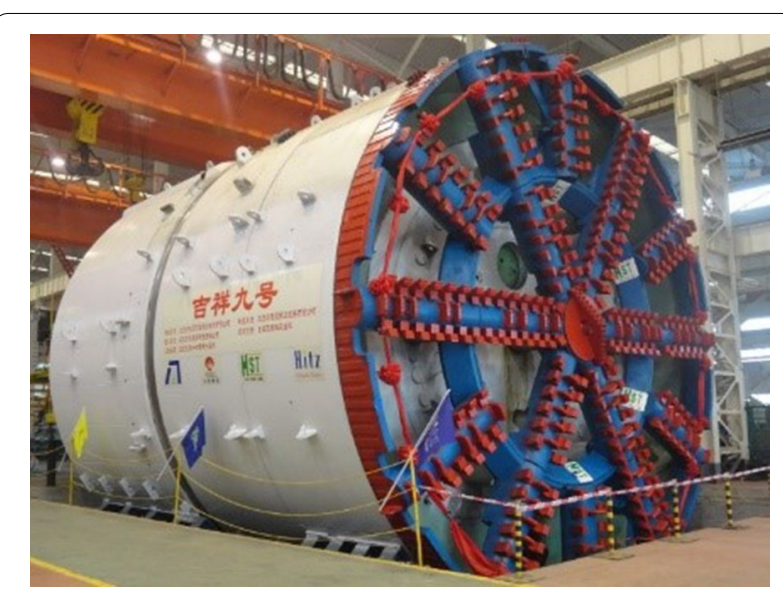

Fig. 3 The used $10.22 \mathrm{~m}$ diameter EPB shield

installed cutterhead torque. The most widely used empirical formula for the installed cutterhead torque of soft ground shield machines is $T=\alpha D^{3}$, where $T$ is cutterhead torque $(\mathrm{kN} \mathrm{m})$, and $D$ is excavation diameter of the machine $(\mathrm{m})$ and $\alpha$ is the maximum torque coefficient. A cross-section of the tunnel is presented in Fig. 4.

\section{Special design of the shield \\ Design of the soil conditioning}

The EPB shield uses the excavated material by the cutting wheel as the support medium to maintain the stability 
Table 2 Important technical parameters of the $10.22 \mathrm{~m}$ diameter shield

\begin{tabular}{ll}
\hline Items & Parameters \\
\hline Excavation diameter $(\mathrm{mm})$ & 10,220 \\
External diameter $(\mathrm{mm})$ & 10,000 \\
Internal diameter $(\mathrm{mm})$ & 9000 \\
Segment thickness $(\mathrm{mm})$ & 500 \\
Segment ring width $(\mathrm{mm})$ & 1800 \\
Configuration of segments & $9(8+1$ keystone) \\
Machine length $(\mathrm{mm})$ & 11550 \\
Cutterhead rotation speed $(\mathrm{r} / \mathrm{min})$ & $0-0.68$ \\
Advance rate $(\mathrm{mm} / \mathrm{min})$ & $0-85$ \\
Total thrust $(\mathrm{kN})$ & 108,000 \\
Maximum torque coefficient $(\mathrm{a})$ & $\mathrm{a}=32.2$ \\
Working torque $(\mathrm{kN} \mathrm{m})$ & $22,896-34,344$ \\
\hline
\end{tabular}

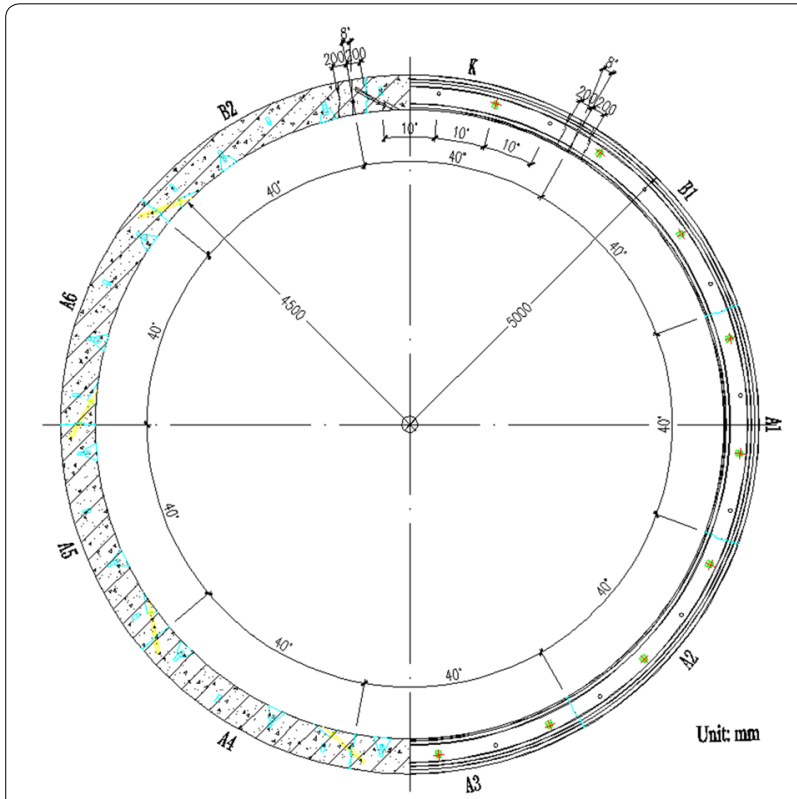

Fig. 4 A cross-section of the tunnel

of the cutting face, and the supporting pressure is heavily dependent on the plastic flow of the muck in the earth chamber. In particular, ensuring high plastic flow of the muck matters when operating the $10.22 \mathrm{~m}$ diameter shield is important because the excavated volume per meter by the machine is nearly 2.8 times greater than that by the $6.15 \mathrm{~m}$ diameter shield. When shield driving in the soils of this project, high fluidity cannot be achieved by filling the excavation chamber with the excavated soil. Moreover, the soil conditioning should take place directly during excavation at the face in front of the cutting wheel to prevent the material sticking to cutting wheels. Besides choosing suitable conditioning agents, the $10.22 \mathrm{~m}$ diameter shield machine should be equipped with necessary components to realize the uniform injection of the agents and the full agitation of the agents with the excavated soils. Three aspects of the machine design were involved in the machine type selection stage: (1) devices for injecting bentonite slurry and foam liquid, and corresponding layouts of pipelines, (2) locations and amounts of injection ports, and (3) the agitating device to actively and independently mix the additives with the soils.

Six slurry pumps and six foam pumps were provided for the $10.22 \mathrm{~m}$ diameter shield machine after the full argumentation and in depth analysis. The additive injection units consisting of injection pumps and injection nozzles located on the cutterhead and in the chamber were determined according to the soil conditions and the machine structure. Twelve additive injection ports were provided at the cutting wheel, bulkhead and crew conveyor of the machine. The injection ports at the cutting wheel are shown in Fig. 5.

Independent pipelines for injecting different conditioning agents were arranged as shown in Figs. 6 and 7.

In addition to the agitating rods attached to the cutterhead and the fixed rods mounted on the bulkhead (see Fig. 8), two independently driven agitators (see Fig. 9), symmetrically arranged on both sides of and near the cutter head center, were employed to enhance the mixing of the excavated soil and additives and to prevent any blocking of the cutting wheel or blockage of the excavation chambers in areas with a low pressure gradient. Full

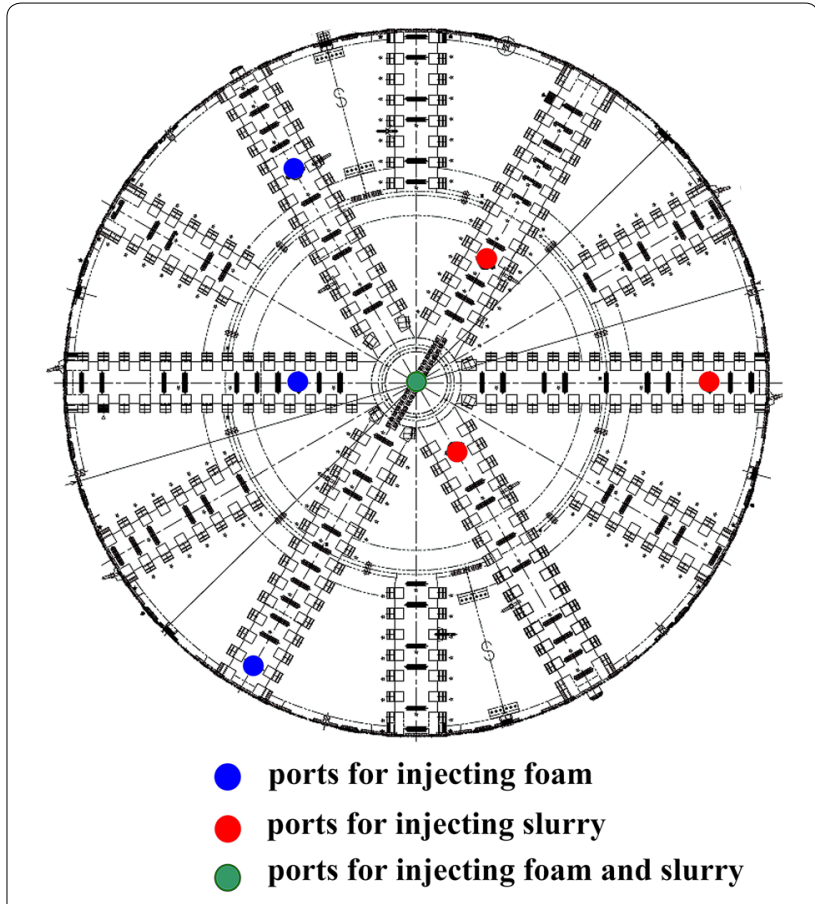

Fig. 5 Injection ports at the cutting wheel 


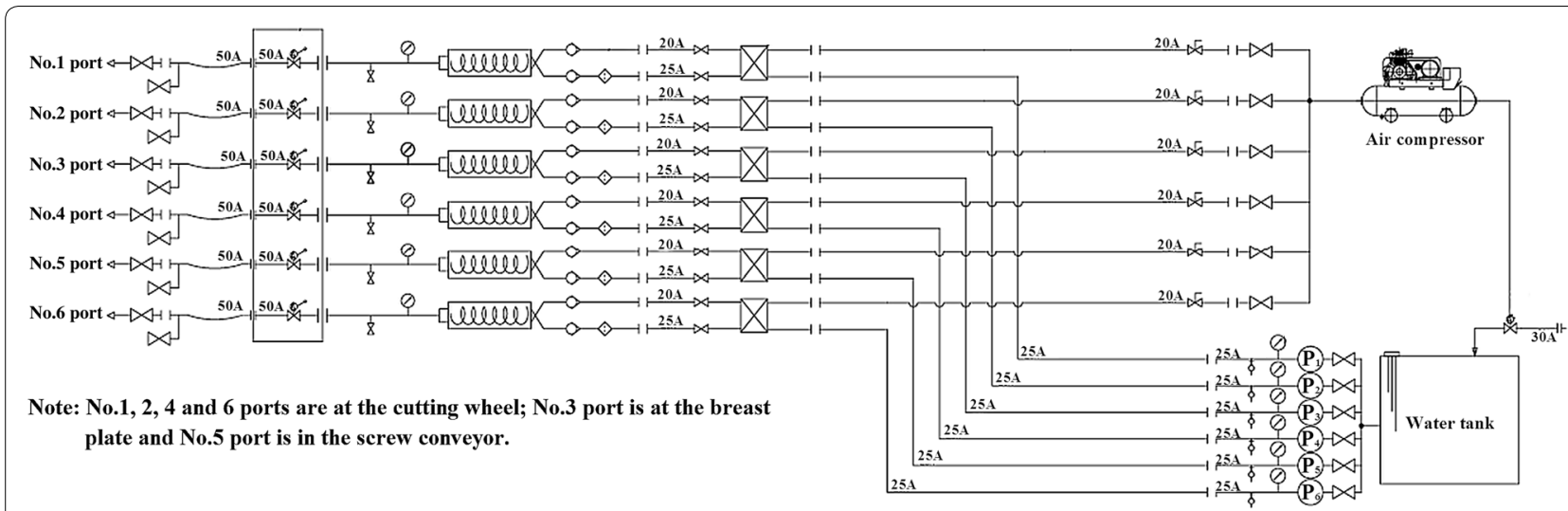

Fig. 6 Diagram of the pipeline layout employed for injecting the foam liquid

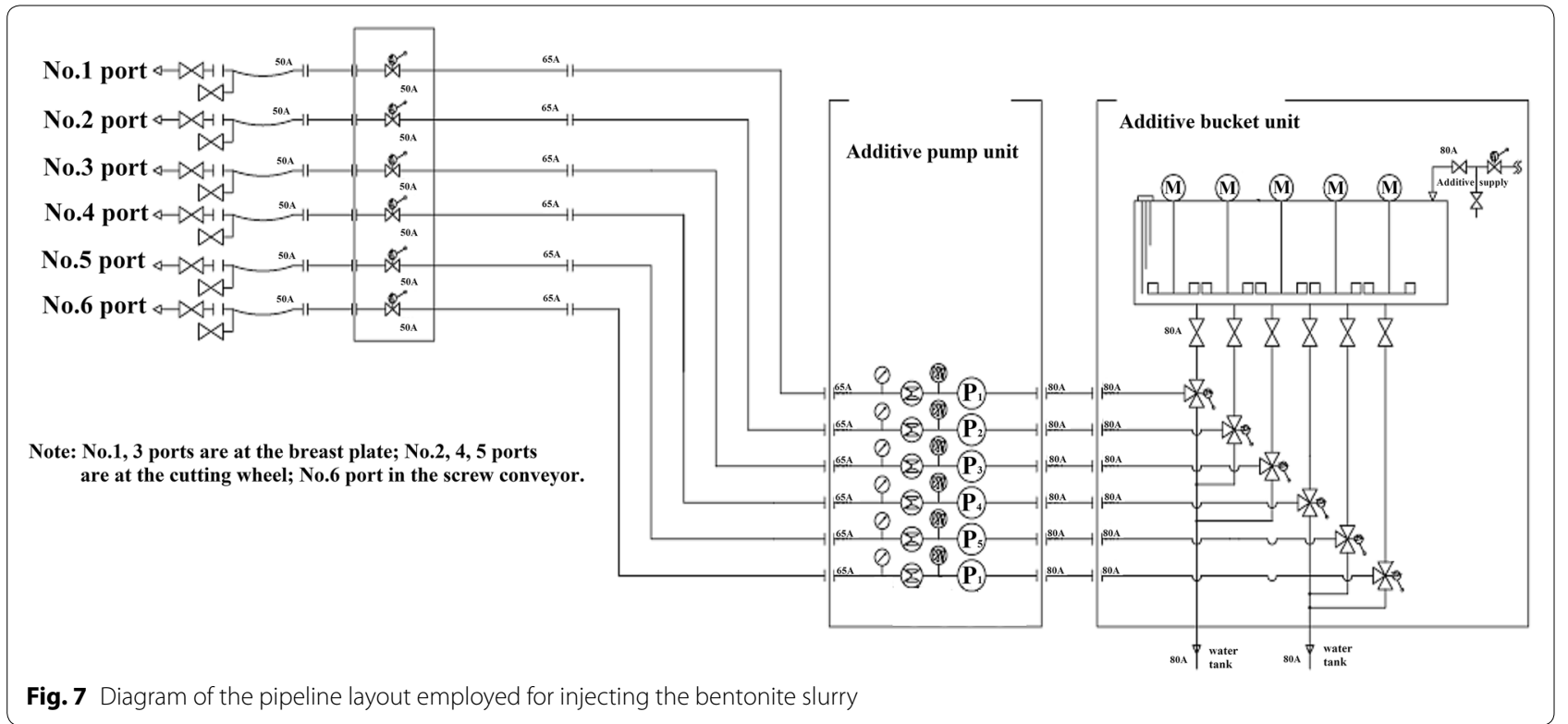

mixing of the excavated soil with the injected additives ensured plastic flow of the muck in the shield driving process.

At the onset of the shield tunneling, the comparison on the cutterhead torque between on and off rotation of the agitators was done to test the functioning of the agitators when the machine at a low advance rate of about $10 \mathrm{~mm} /$ min. An about 20\% increase in the torque resulted when switching off the agitators. It was expected that the agitators would play a more important role when shield advancing at the normal rate of $50 \mathrm{~mm} / \mathrm{min}$.

\section{Grouting equipment}

In view of the efficacy of confining the ground movements of backfilling using the two-component grouts, two-component system injection is progressively substituting the traditional use of cementitious mortars (Peila et al. 2011). The equipment for the two-component system was required for the $10.22 \mathrm{~m}$ diameter shield. Five sets of simultaneous backfilling grouting systems were arranged at five positions along the circumference of the $10.22 \mathrm{~m}$ diameter shield, as shown in Fig. 10. The system consisted of injection pipelines for A-liquid and/or B-liquid, injection jacks, oil-pressure pipes for the injection jack, water injection pipelines, a front switch, a back switch, a ball valve, oil-pressure pipes and injection ports. Additionally, three pumps for the A-liquid, three pumps for the B-liquid, two water pumps, and corresponding storage tanks, pipelines were provided. 


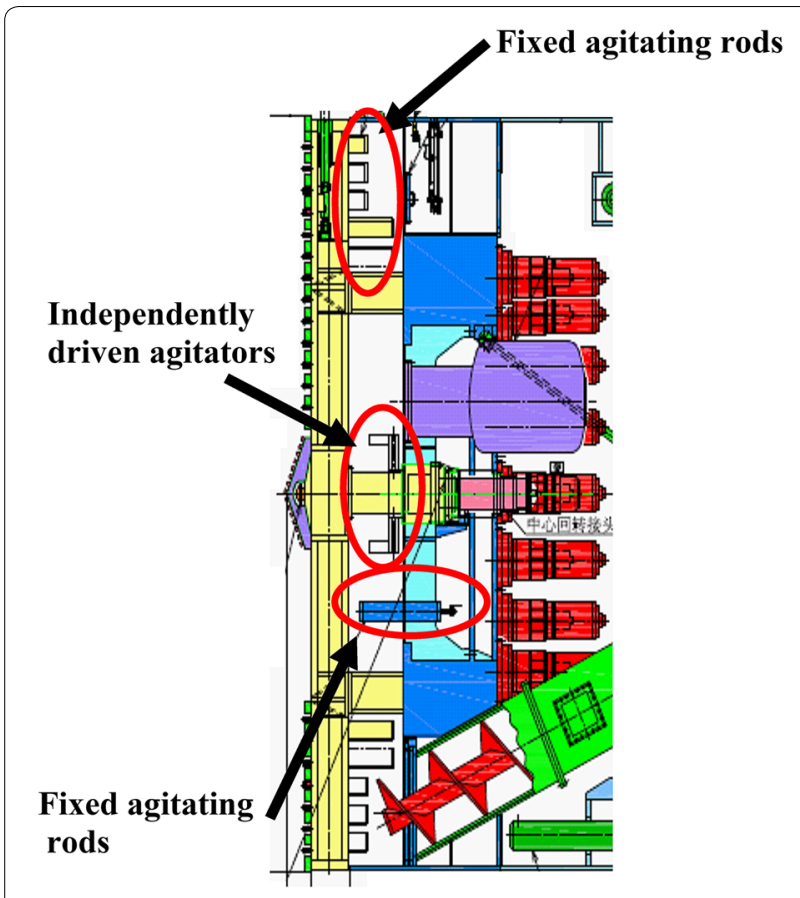

Fig. 8 Fixed agitating rods and independently driven agitators

\section{Key shield tunneling technologies}

Since the shield passed underneath the densely built-up areas of the city, influences of the shield tunneling were strictly controlled within the accepted levels. In addition, it was critical that the shield tunnel construction was completed as scheduled. Any delay to cope with the influences could slow down or obstruct shield machine operations if not properly handled. To allow for safe and accurate tunnel excavation at a normal speed and without adverse effects on the surroundings, two shield tunneling technologies should be highlighted: soil conditioning and simultaneous backfilling grouting.

\section{Soil conditioning}

To use the removed soil from the face as a support medium, it should possess the following properties: (1) high plastic ductility, (2) pasty to soft consistency, (3) low internal friction, and (4) low water permeability (Maidl et al. 2012). When using the $6.15 \mathrm{~m}$ diameter EPB shields in Beijing, the slump of the muck is often employed to evaluate the properties of the conditioned soils, and the slumps in the range of 100-150 $\mathrm{mm}$ (vane shear strength of $0-5 \mathrm{kPa}$ ) are appropriate to serve as the support medium to counteract soil and water pressure at the cutting face, which is the experience gained from the past shield tunneling in Beijing. The soils encountered in this shield driving have a slump of approximately $55 \mathrm{~mm}$ in their natural state, hence most have to be conditioned. Soil conditioning can be conducted by the addition of either bentonite or foam, or of both. To further verify suitable conditioning agents and determine the injection volume, a combination of indoor experiments and in situ experiments was used in the project.

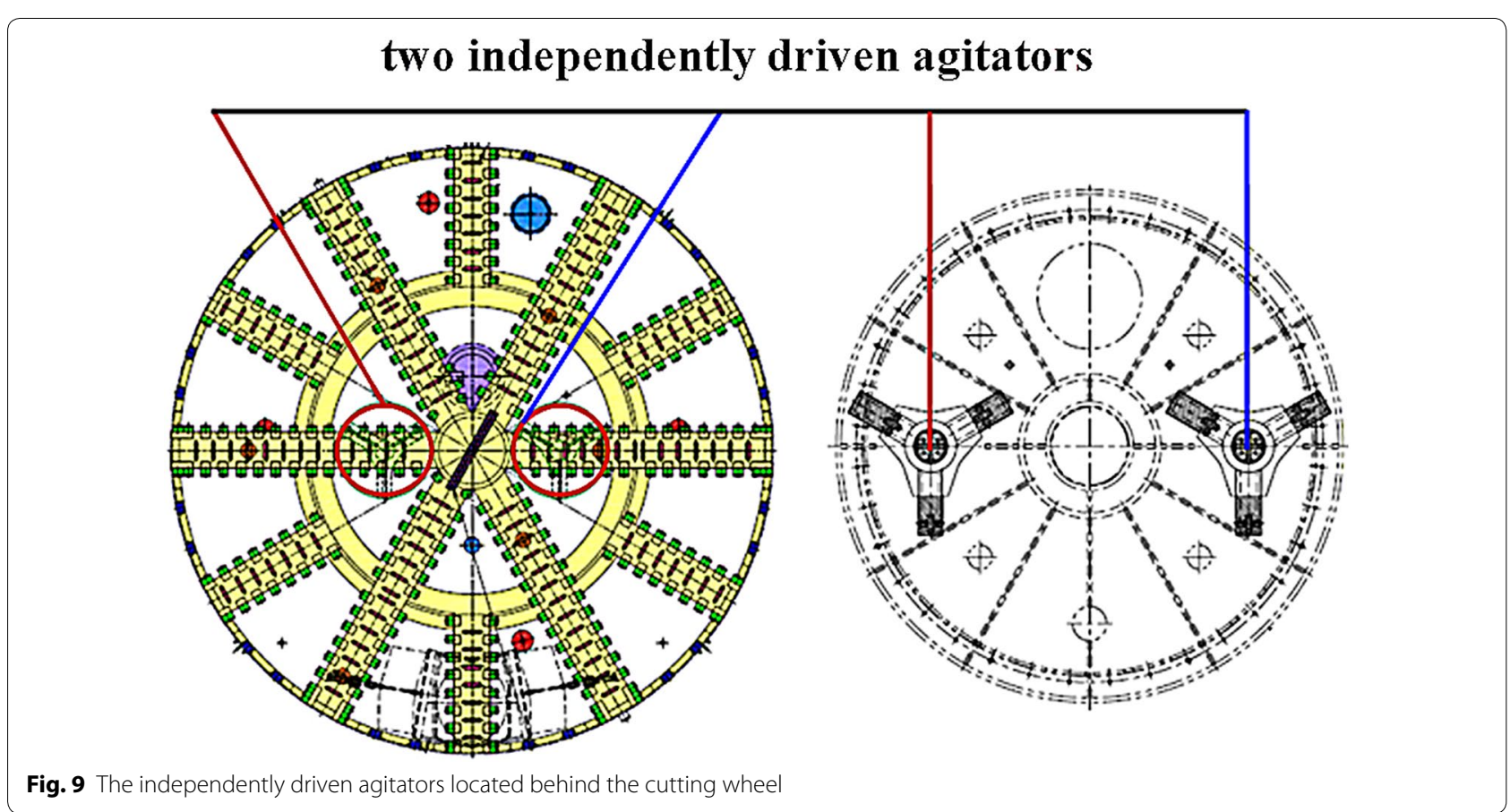




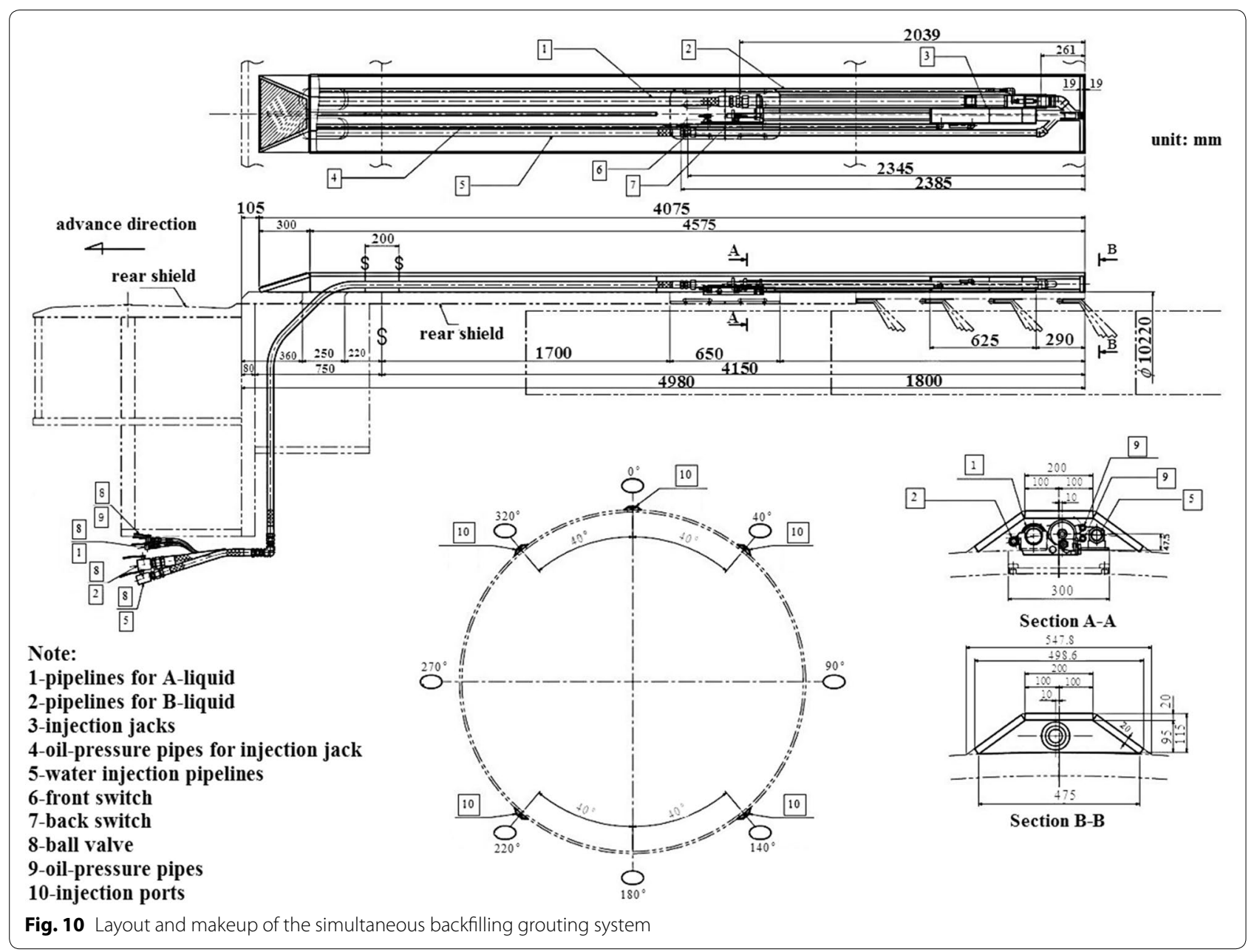

\section{Indoor tests}

In indoor tests, the conditioning effects was tested by injecting bentonite and foam individually, and injecting both of them simultaneously. In the experiments, sodium bentonite was adopted with a colloid index of more than $400 \mathrm{ml} / 15 \mathrm{~g}$ and an expansion rate of more than $25 \mathrm{ml} / \mathrm{g}$. The conditioning effects varies with the bentonite slurry concentration (Concn) and the bentonite injection ratio (BIR). Field experience in Beijing has indicated that a bentonite slurry with a Concn of $8 \%$ achieves optimal results. This bentonite slurry was used in the indoor experiments to condition the silt with different BIRs. The measured slumps of the samples are given in Table 3 . The properties of the foaming agent used are listed in Table 4. The slumps were recorded for the tested silt samples with the various foam injection ratios (FIRs) and foam expansion ratios (FERs), as presented in Table 5. In Table 5, the foam height was measured as the Ross-Miles method (Al-Sabagh et al. 2003): $200 \mathrm{ml}$ of a solution of surfactant contained in a pipette of specified dimensions with a $2.9 \mathrm{~mm}$ internal diameter, from the orifice $90 \mathrm{~cm}$ are allowed to fall onto $50 \mathrm{ml}$ of same solution contained in a cylindrical vessel maintained at a given temperature by means of a water jacket. The height of the foam produced

Table 3 Measured slumps of the samples with different BIRs

\begin{tabular}{|c|c|c|c|c|c|c|}
\hline Concn of the bentonite slurry (\%) & Water (kg) & Bentonite (kg) & Density $\left(\mathrm{g} / \mathrm{cm}^{3}\right)$ & Viscosity (s) & BIR (\%) & Slump (mm) \\
\hline \multirow[t]{3}{*}{8} & 1000 & 89 & 1.04 & 27 & 15 & 78 \\
\hline & & & & & 10 & 72 \\
\hline & & & & & 5 & 65 \\
\hline
\end{tabular}


Table 4 Properties of the foaming agent

\begin{tabular}{ll}
\hline Items & Index \\
\hline Appearance & Colorless transparent liquid \\
Water solubility & Completely soluble \\
Density, $25^{\circ} \mathrm{C}$ & $1.01 \pm 0.02 \mathrm{~g} / \mathrm{cm}^{3}$ \\
PH value & $7-8$ \\
Foaming capacity (Ross-Miles) & $\geq 220 \mathrm{~mm}$ \\
\hline
\end{tabular}

in the cylindrical vessel was read immediately after all the solution had run out of the pipette (initial foam height) and again after a given amount of time (generally $5 \mathrm{~min}$ ). Properties of the soil samples are listed in Table 6.

The scheme involved the simultaneous injection of the bentonite slurry and foam liquid to condition the excavated soil. Based on construction experiences in similar geologic conditions, three recipes were tested: (1) $8 \%$ bentonite slurry with $5 \%$ foam liquid, (2) $6 \%$ bentonite slurry with $7 \%$ foam liquid and (3) $10 \%$ bentonite slurry with $3 \%$ foam liquid. In the indoor tests, various injection ratios were used for the soil samples. Recorded slumps of the samples are listed in Tables 7, 8 and 9. It was found that the first recipe of the $8 \%$ bentonite slurry with the $5 \%$ foam liquid achieved the best results.

\section{Field tests}

For construction of the shield tunnels in Beijing, which were a little more than $6 \mathrm{~m}$ in outer diameter, slumps of approximately $130 \mathrm{~mm}$ of the conditioned soils were sufficient. In the initial construction stage of the project, it was attempted to use the existing conditioning scheme in the shield driving. However, operation of the $10.22 \mathrm{~m}$ diameter shield was difficult. The earth chamber pressure, cutterhead torque and total thrust fluctuated widely, and large clods of earth existed, resulting in obvious ground surface settlement and a wider settlement trough. It was absolutely necessary to perform field tests to further optimize the conditioning scheme based on the indoor experiments. Considering the ease of operation and engineering economy, the scheme of simultaneously injecting $8 \%$ bentonite slurry and 5\% foam liquid was adopted in the field tests based on the above findings. Through the field tests, the differences in conditions between the indoor tests and the construction were justified and the actual effects of the conditioning agent and the injection ratios were further verified. The test sections is given in Fig. 11 and properties of the soils are presented in Table 10.

According to the results presented in Tables 7, 8 and 9, six formulations of foam liquid and bentonite slurry were used in the in situ tests:

1. The No. 1 formulation: $15 \%$ of FIR (Concn of 5\%, FER of 12 ) and $6 \%$ of BIR (Concn of $8 \%$ );

2. The No. 2 formulation: $30 \%$ of FIR (Concn of 5\%, FER of 12 ) and $6 \%$ of BIR (Concn of $8 \%$ );

3. The No. 3 formulation: $15 \%$ of FIR (Concn of 7\%, FER of 12 ) and $6 \%$ of BIR (Concn of 6\%);

4. The No. 4 formulation: $30 \%$ of FIR (Concn of 7\%, FER of 12 ) and $6 \%$ of BIR (Concn of 6\%);

5. The No. 5 formulation: $15 \%$ of FIR (Concn of 3\%, FER of 12 ) and $6 \%$ of BIR (Concn of 10\%);

6. The No. 6 formulation: 30\% of FIR (Concn of 3\%, FER of 12 ) and $6 \%$ of BIR (Concn of $10 \%$ ).

In general, the well-controlled shield operation could be achieved when the slumps of the muck were more than $160 \mathrm{~mm}$, with shield tunneling parameters remaining almost stable, as given in Figs. 13, 14 and 15. However, when the slumps reached $180 \mathrm{~mm}$, the construction efficiency was significantly affected due to the difficulty in muck transport by the belt conveyor. Thus, the overly large slumps of the muck were not suitable. Higher earth chamber pressure and lower ground surface settlement were obtained when using the No. 1 and 2 formulations to condition the soil, as shown in Figs. 12 and 15. The surface settlement profiles in Fig. 15 were measured after grouting. When shield driving passing the test sections, the key shield operational parameter including grout injection volume were controlled at almost the same level to understand the conditioning effects using foam. The test sections were arranged with a spacing of more than $20 \mathrm{~m}$, resulting the same influence of the test section locations on the measured settlements. Considering the ease of

Table 5 Measured slumps of the samples with different FIRs and FERs

\begin{tabular}{|c|c|c|c|c|c|c|}
\hline Concn of the foam liquid (\%) & Mass of the foam liquid (kg) & Water (kg) & FER & FIR (\%) & Density $\left(\mathrm{g} / \mathrm{cm}^{3}\right)$ & Slump (mm) \\
\hline \multirow[t]{6}{*}{5} & 50 & 950 & 10 & 15 & 1.96 & 82 \\
\hline & & & & 20 & 1.92 & 85 \\
\hline & & & 12 & 15 & 1.93 & 84 \\
\hline & & & & 20 & 1.87 & 87 \\
\hline & & & 15 & 15 & 1.89 & 72 \\
\hline & & & & 20 & 1.81 & 72 \\
\hline
\end{tabular}


Table 6 Properties of the silt samples

\begin{tabular}{llllll}
\hline $\begin{array}{l}\text { Soil } \\
\text { sample }\end{array}$ & $\begin{array}{l}\text { Natural } \\
\text { density } \\
\left(\mathbf{g} / \mathbf{c m}^{\mathbf{3}}\right)\end{array}$ & $\begin{array}{l}\text { Dry } \\
\text { density } \\
\left(\mathbf{g} / \mathbf{c m}^{3}\right)\end{array}$ & Porosity & $\begin{array}{l}\text { Liquid } \\
\text { limit (\%) }\end{array}$ & $\begin{array}{l}\text { Plastic } \\
\text { limit } \\
\mathbf{( \% )}\end{array}$ \\
\hline Silt & 2.08 & 1.76 & 0.349 & 26.1 & 17.6 \\
\hline
\end{tabular}

Table 7 Recorded slumps of the samples using the first recipe (unit:mm)

\begin{tabular}{lccc}
\hline BIR of the 8\% bentonite slurry (\%) & $\mathbf{4 . 0}$ & $\mathbf{6 . 0}$ & $\mathbf{8 . 0}$ \\
\hline FIR of the foam liquid (5\% of Concn and 10 of FER) (\%) & & \\
10 & 105 & 140 & 179 \\
15 & 124 & 166 & 199 \\
30 & 151 & 189 & 215 \\
FIR of the foam liquid (5\% of Concn and 12 of FER) (\%) & & \\
10 & 102 & 137 & 175 \\
15 & 117 & 165 & 192 \\
30 & 143 & 185 & 211 \\
FIR of the foam liquid (5\% of Concn and 15 of FER) (\%) & & \\
10 & 98 & 130 & 164 \\
15 & 103 & 138 & 176 \\
30 & 118 & 155 & 190 \\
\hline
\end{tabular}

The italics in the tables present the results with the most appropriate FER of the foam liquid

Table 8 Recorded slumps of the samples using the second recipe (unit:mm)

\begin{tabular}{lccc}
\hline BIR of the $\mathbf{6 \%}$ bentonite slurry (\%) & $\mathbf{4 . 0}$ & $\mathbf{6 . 0}$ & $\mathbf{8 . 0}$ \\
\hline FIR of the foam liquid (7\% of Concn and 10 of FER) (\%) & & \\
10 & 96 & 127 & 158 \\
15 & 108 & 142 & 174 \\
30 & 133 & 165 & 199 \\
FIR of the foam liquid (7\% of Concn and 12 of FER) (\%) & & \\
10 & 96 & 128 & 155 \\
15 & 107 & 140 & 170 \\
30 & 132 & 163 & 192 \\
FIR of the foam liquid (7\% of Concn and 15 of FER) (\%) & & \\
10 & 91 & 122 & 150 \\
15 & 96 & 128 & 160 \\
30 & 108 & 142 & 175
\end{tabular}

The italics in the tables present the results with the most appropriate FER of the foam liquid

the operation, the conditioning scheme using the No. 1 formulation was suggested; however, the scheme using the No. 2 formulation was used, when more sand in the soils, with the increased injection ratio of the foam liquid. Variations of the total thrust and cutterhead torque with different formulations, as shown in Figs. 13 and 14, may
Table 9 Recorded slumps of the samples using the third recipe (unit:mm)

\begin{tabular}{lccc}
\hline BIR of the $\mathbf{1 0 \%}$ bentonite slurry (\%) & $\mathbf{4 . 0}$ & $\mathbf{6 . 0}$ & $\mathbf{8 . 0}$ \\
\hline FIR of the foam liquid (3\% of Concn and 10 of FER) (\%) & & \\
10 & 77 & 110 & 153 \\
15 & 95 & 135 & 170 \\
30 & 120 & 161 & 189
\end{tabular}

FIR of the foam liquid (3\% of Concn and 12 of FER) (\%)

$\begin{array}{rrrr}10 & 70 & 109 & 144 \\ 15 & 89 & 129 & 163 \\ 30 & 111 & 156 & 185\end{array}$

FIR of the foam liquid (3\% of Concn and 15 of FER) (\%)

$\begin{array}{llll}10 & 65 & 102 & 135 \\ 15 & 72 & 110 & 147 \\ 30 & 85 & 125 & 164\end{array}$

The italics in the tables present the results with the most appropriate FER of the foam liquid

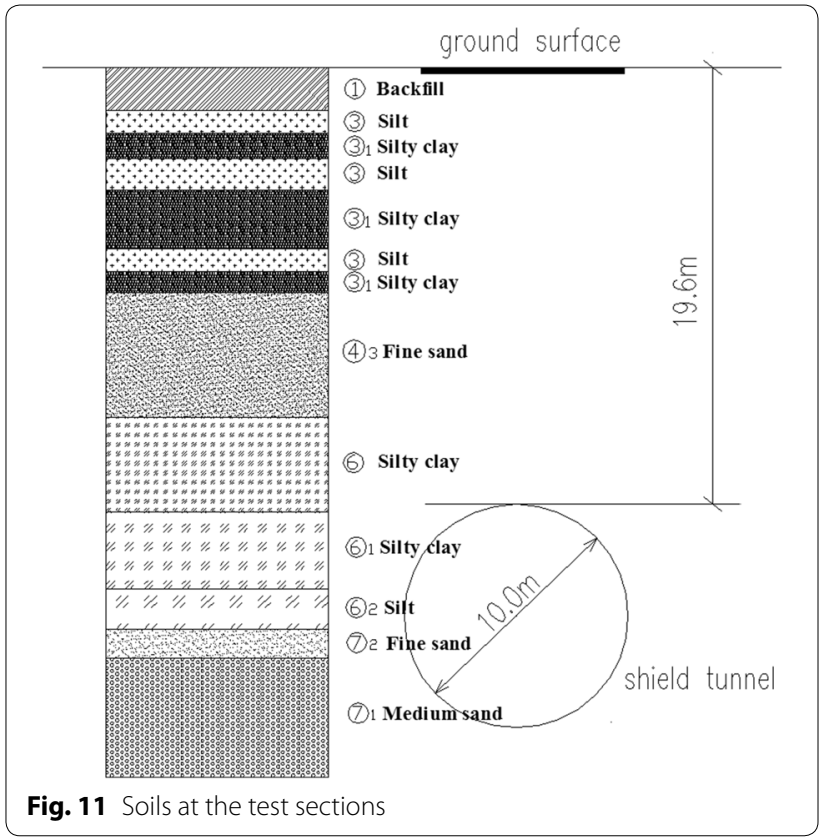

have led to friction changes caused by different additives between the cutterhead, shield skin and soils.

\section{Grouting work}

In practice, grouting of shield tunneling includes grouting of the tail void (first phase injection) and grouting directly through segments (second phase injection) (Guglielmetti et al. 2008). Based on previous experience in Beijing, attention was paid to the first phase injection, and a two-component grout was used in the injection. 


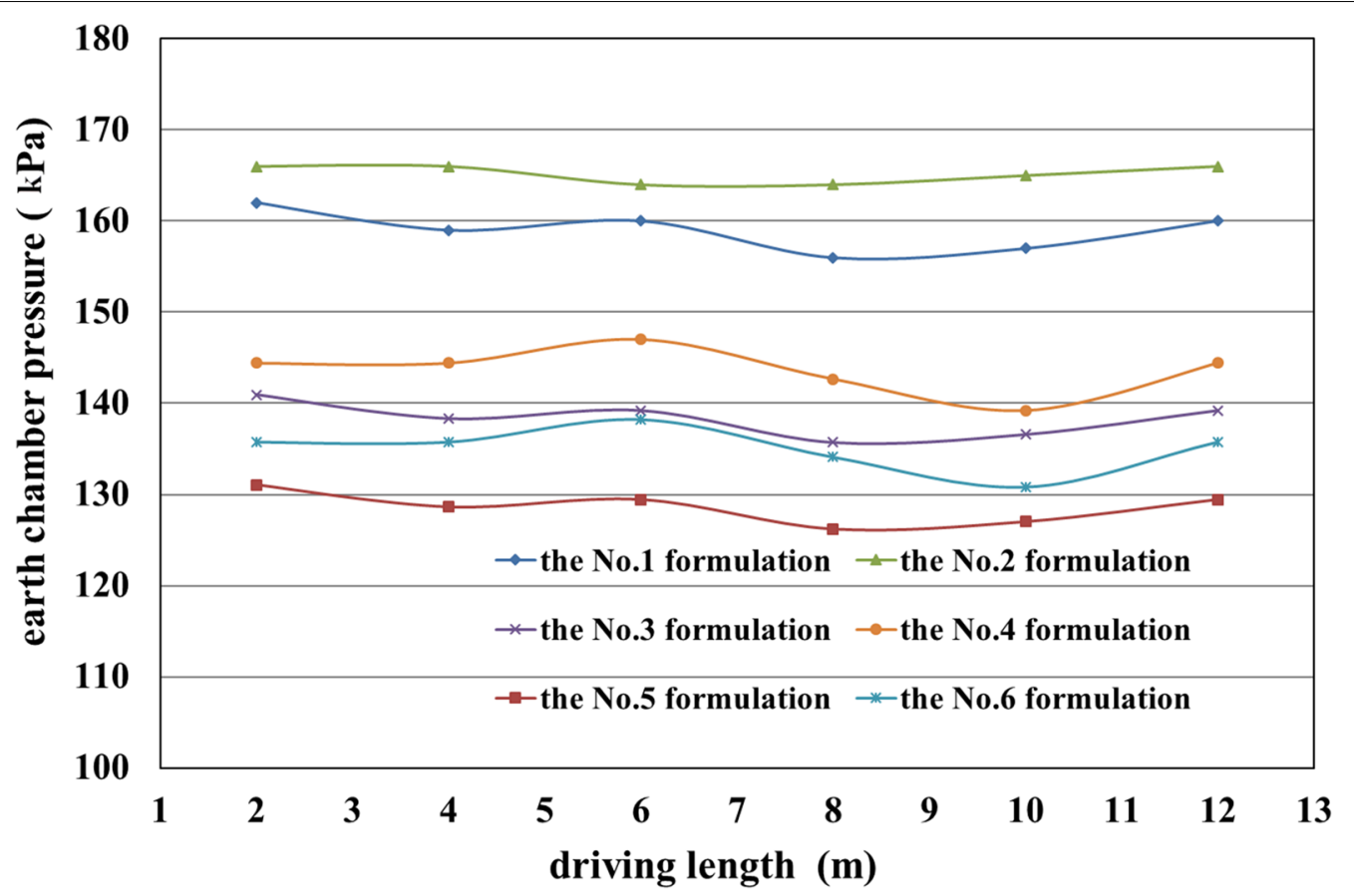

Fig. 12 Recorded earth chamber pressure

Table 10 Properties of the soils at the test sections

\begin{tabular}{|c|c|c|c|c|c|c|}
\hline Name & Natural density $\left(\mathrm{g} / \mathrm{cm}^{3}\right)$ & Dry density $\left(\mathrm{g} / \mathrm{cm}^{3}\right)$ & Porosity & Liquid limit (\%) & Plastic limit (\%) & SPT N-values \\
\hline Backfill (1) & 1.65 & - & - & - & - & - \\
\hline Silt (3) & 2.02 & 1.67 & 0.369 & 26.3 & 19.2 & - \\
\hline Silty clay (3) & 1.90 & 1.46 & 0.463 & 36.9 & 24.3 & - \\
\hline Fine sand (4) 3 & 2.02 & - & - & - & - & 31 \\
\hline Silty clay (6) & 2.03 & 1.66 & 0.389 & 31.8 & 19.6 & - \\
\hline Silty clay (6) & 1.89 & 1.43 & 0.476 & 40.9 & 24.9 & - \\
\hline Silt (6) 2 & 2.08 & 1.76 & 0.349 & 26.1 & 17.6 & - \\
\hline Medium sand (7) & 2.10 & - & - & - & - & 53 \\
\hline Fine sand $(7)_{2}$ & 2.05 & - & - & - & - & 44 \\
\hline
\end{tabular}

The A-liquid mainly consisted of cement and bentonite ( $8 \%$ of Concn); the B-liquid consisted of sodium silicate (30 of Baume degree, specific gravity of about 1.26 ). To reduce the surface settlement to the largest degree, the coagulation time of the grout was controlled to be within 15-20 s by adjusting the mix ratios of the A-liquid to the B-liquid; meanwhile, an injection volume of $14.1-15.3 \mathrm{~m}^{3}$ was used in each segmental ring. The grout injection adopted was mainly based on the measured surface settlement.

\section{Tests of the A-liquid}

Sodium bentonite from two places of origin (Weifang of Shandong Province and Chengde of Hebei Province of
China) and slurries of two concentrations were used to prepare the tests of the A-liquid. The recorded results are listed in Table 11. It is shown that the slurry with a Concn of $9 \%$ is prone to choking the injection device and the pipelines and is thus unfit for field applications. The market price of the A-liquid was also investigated, as shown in Table 12. In the some of the cells, two numbers mean materials were added twice and the plus-signs in the cells means that water was added twice. IST (Initial setting time) is the time at which grout paste loses its plasticity. After a comprehensive comparison, it was determined that bentonite slurry (yellowish white) $8 \%$ in Concn from Chengde of Hebei Province was used to prepare the 


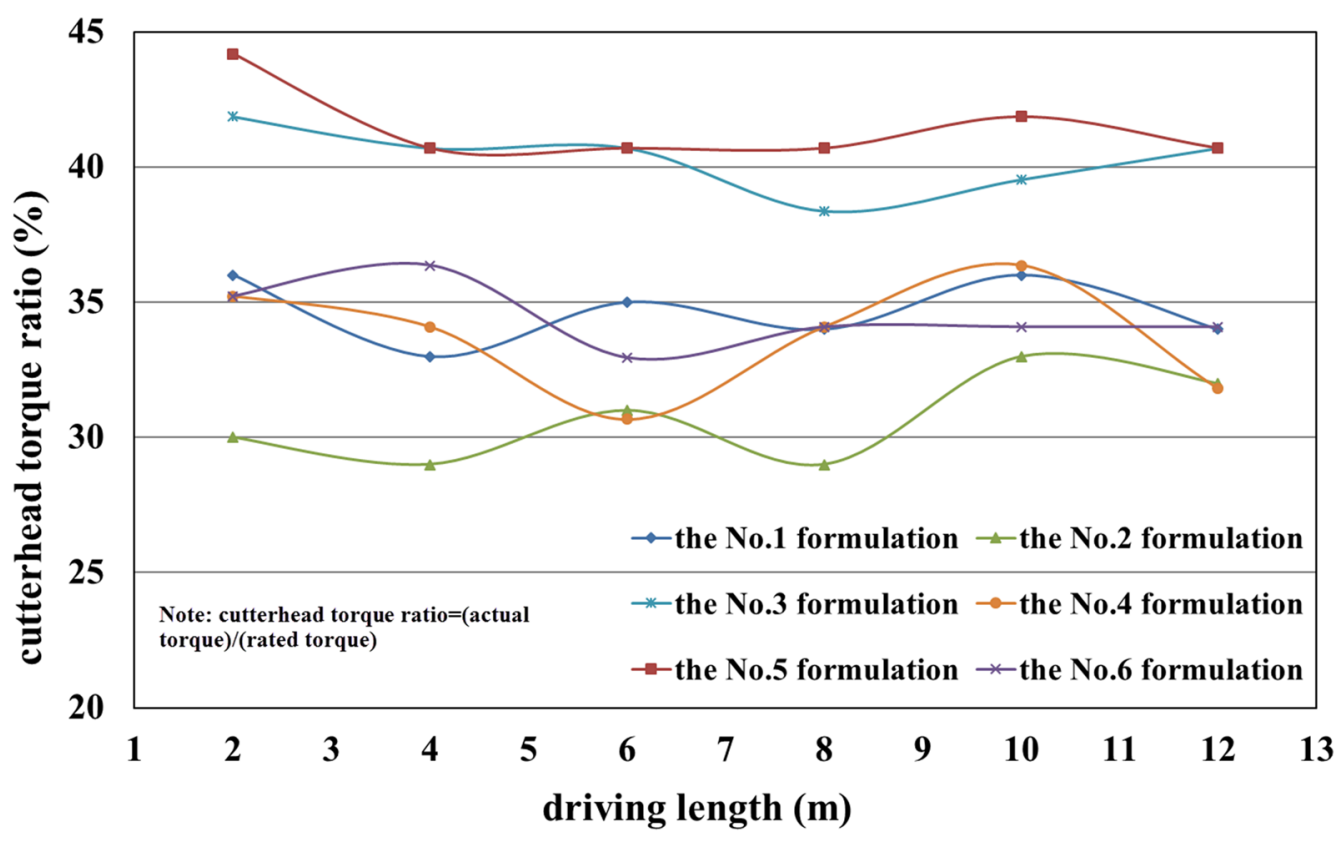

Fig. 13 Recorded cutterhead torque

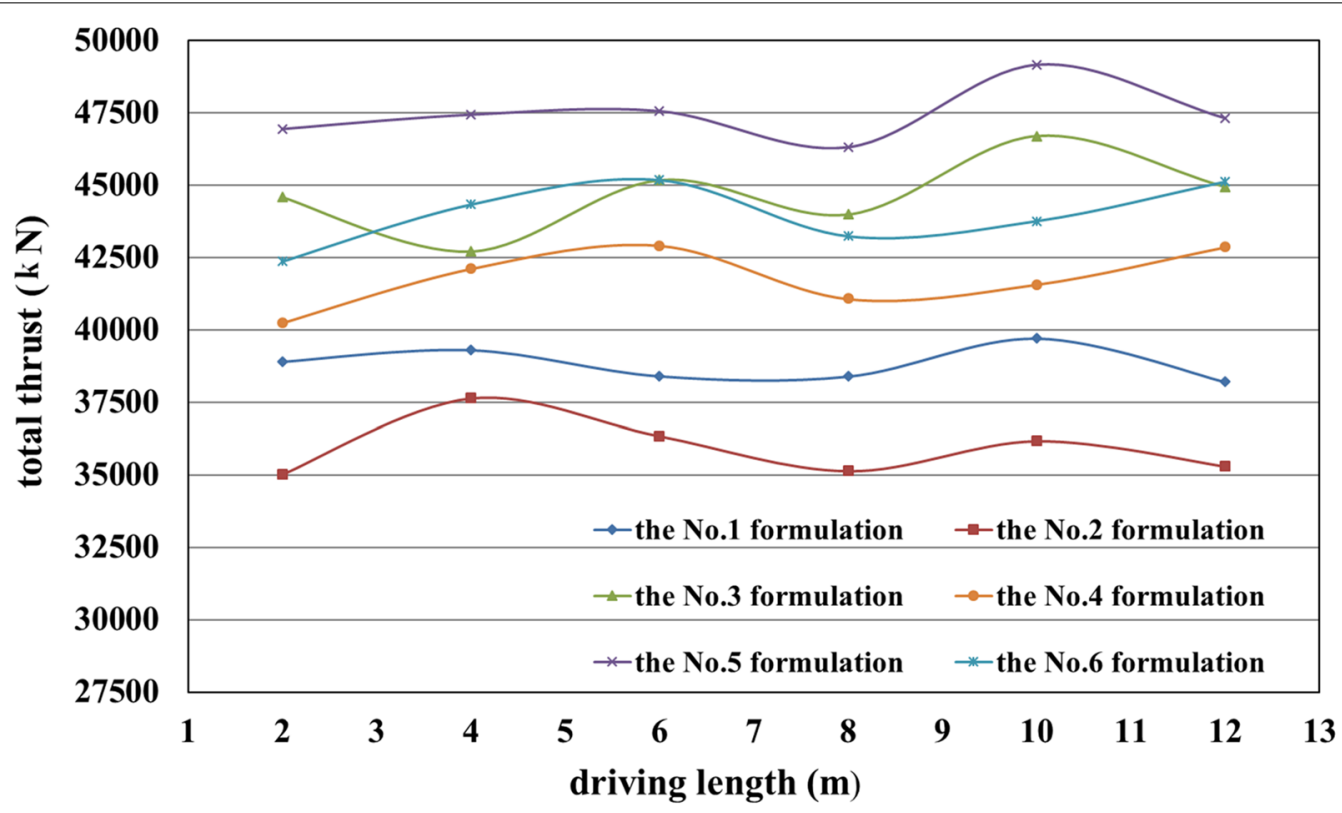

Fig. 14 Recorded total thrust

A-liquid. The specific gravity of the slurry was 1.19 and the viscosity was $37.66 \mathrm{~s}$.

\section{Tests of mixing the A-liquid and B-liquid}

Firstly, the A-liquid was prepared by mixing different materials, and then tests of mixing A-liquid and B-liquid were performed. The results of the tests are given in
Table 13. In Table 13, Final setting time is the time when the paste completely loses its plasticity. It is the time taken for the grout paste to harden sufficiently.

\section{Determining the mix ratio of the grout}

The grout for backfilling the annulus gap should have a higher coagulation rate under the premise that the 
distance from the tunnel centerline $(\mathrm{m})$

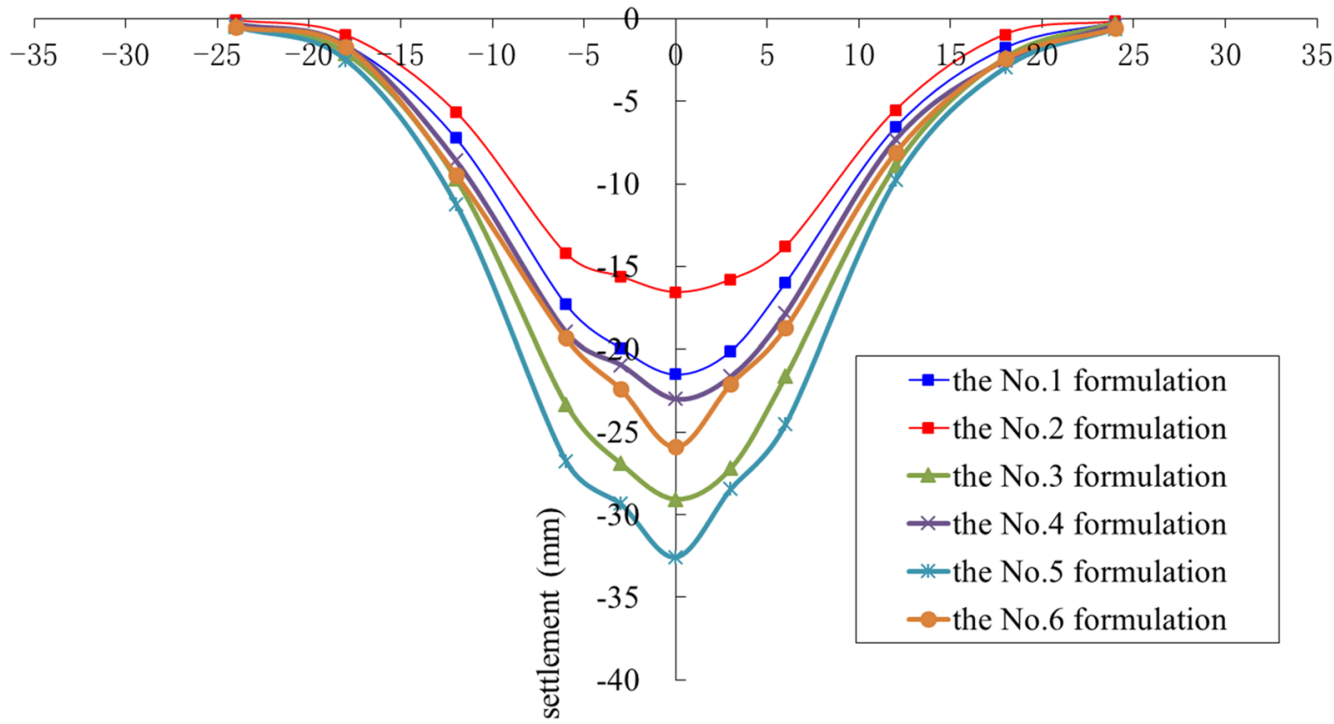

Fig. 15 Measured ground surface settlements

Table 11 Test results of the A-liquid

\begin{tabular}{|c|c|c|c|c|c|c|c|}
\hline \multirow[t]{3}{*}{ Place of origin of the sodium bentonite } & \multicolumn{5}{|c|}{ Mix ratio of the A-liquid in mass } & \multirow{3}{*}{$\begin{array}{l}\text { Density } \\
\left(\mathrm{g} / \mathrm{cm}^{3}\right)\end{array}$} & \multirow{3}{*}{$\begin{array}{l}\text { Funnel discharge } \\
\text { time (s) }\end{array}$} \\
\hline & \multirow[t]{2}{*}{ Water } & \multirow[t]{2}{*}{ Cement } & \multirow[t]{2}{*}{ Retarder } & \multicolumn{2}{|c|}{$\begin{array}{l}\text { Concentration } \\
\text { of the bentonite } \\
\text { slurry }\end{array}$} & & \\
\hline & & & & $8 \%$ & $9 \%$ & & \\
\hline \multirow[t]{2}{*}{ Weifang of Shandong Province, red appearance } & 1 & 1 & 0.016 & 3.52 & & 1.16 & 38.37 \\
\hline & 1 & 1 & 0.016 & & 3.13 & 1.19 & 115 \\
\hline \multirow{2}{*}{ Chengde of Hebei Province, yellowish white appearance } & 1 & 1 & 0.016 & 3.52 & & 1.19 & 37.66 \\
\hline & 1 & 1 & 0.016 & & 3.13 & 1.20 & 65.84 \\
\hline
\end{tabular}

quick solidification of the grout does not choke the pipelines. After analyzing the test results and other data available, the solidification time of the grout was adopted to be $16.4 \mathrm{~s}$, and the corresponding mix ratio of water:cement:slurry:retarder is 1:1:0.3:0.013.

Variations in the strength of the grout test block with age are given in Fig. 16, which is the test result of mixing the A-liquid and B-liquid. This type of grout is quickly solidified, with a rapid increase in strength, resulting in higher strength at 28 days, and quick or even immediate support to the surrounding ground.

\section{Performances of the shield machine}

During long distance driving of the shield, the scheme of simultaneously injecting foam and bentonite using the No. 1 formulation was usually adopted to control slumps of the excavated soils at approximately $160 \mathrm{~mm}$. However, in difficult situations, such as passing large cross sections of sand soils or crucial risk sources, the injection scheme of the No. 2 formulation was used to increase the injection ratio of the foam. Compared with the No. 1 formulation, more foam was used in the No. 2 formulation. This led to the high earth chamber pressure, the less cutterhead torque and total thrust, and more importantly the small surface settlement. So the No. 2 formulation was used to get the small settlement in more difficult conditions. Generally, the above guidelines were executed in the whole tunnel construction, and the shield tunneling parameters were well regulated. The key parameters were as follows: earth pressure in the excavation chamber of approximately $0.12-0.18 \mathrm{MPa}$, total thrust of approximately $30,000-50,000 \mathrm{kN}$, cutterhead torque of 
Table 12 Market prices of the A-liquids of different mix ratios in China

\begin{tabular}{|c|c|c|c|c|c|c|c|c|}
\hline Materials & Water & Cement & Slurry & Retarder & SG & IST (s) & $\mathrm{TP}\left(¥ / \mathrm{m}^{3}\right)$ & Evaluation \\
\hline \multicolumn{9}{|l|}{1} \\
\hline Mix ratio & 1 & 1 & 0.3 & 0.013 & 1.32 & 16 & 209.75 & The most reasonable \\
\hline \multirow[t]{2}{*}{ Mass (kg) } & $571+157.6$ & 571 & 171.3 & 7.423 & & & & \\
\hline & 728.6 & & 13.7 & & & & & \\
\hline Price $(¥)$ & 4.4 & 179.9 & 6.85 & 18.6 & & & & \\
\hline \multicolumn{9}{|l|}{2} \\
\hline Mix ratio & 1 & 0.9 & 0.3 & 0.01 & 1.27 & 35 & 188.64 & $\begin{array}{l}\text { Merits: low price; defects: long setting } \\
\text { time and unfit for construction }\end{array}$ \\
\hline $\begin{array}{l}\text { Changed Mix } \\
\text { ratio }\end{array}$ & 1.11 & 1 & 0.33 & 0.0111 & & & & \\
\hline \multirow[t]{2}{*}{ Mass (kg) } & $574.7+158.6$ & 517.19 & 172.40 & 5.747 & & & & \\
\hline & 733.3 & & 13.8 & & & & & \\
\hline Price (¥) & 4.47 & 162.9 & 6.9 & 14.37 & & & & \\
\hline \multicolumn{9}{|l|}{3} \\
\hline Mix ratio & 1 & 0.9 & 0.2 & 0.008 & 1.29 & 20 & 195.06 & $\begin{array}{l}\text { Merits: low price; defects: long setting } \\
\text { time and unfit for construction }\end{array}$ \\
\hline $\begin{array}{l}\text { Changed Mix } \\
\text { ratio }\end{array}$ & 1.11 & 1 & 0.22 & 0.009 & & & & \\
\hline \multirow[t]{2}{*}{ Mass (kg) } & $611.95+112.6$ & 550.76 & 122.39 & 4.896 & & & & \\
\hline & 724.6 & & 9.79 & & & & & \\
\hline Price $(¥)$ & 4.42 & 173.5 & 4.9 & 12.24 & & & & \\
\hline \multicolumn{9}{|l|}{4} \\
\hline Mix ratio & 1 & 0.8 & 0.2 & 0.008 & 1.24 & 36 & 177.37 & $\begin{array}{l}\text { Merits: low price; defects: long setting } \\
\text { time and unfit for construction }\end{array}$ \\
\hline $\begin{array}{l}\text { Changed Mix } \\
\text { ratio }\end{array}$ & 1.25 & 1 & 0.25 & 0.01 & & & & \\
\hline \multirow[t]{2}{*}{ Mass (kg) } & $617.53+113.63$ & 494.02 & 123.51 & 4.94 & & & & \\
\hline & 731.16 & & 9.88 & & & & & \\
\hline Price $(¥)$ & 4.46 & 155.62 & 4.94 & 12.35 & & & & \\
\hline
\end{tabular}

SG specific gravity, IST initial setting time, TP total price

approximately $30-45 \%$ of the rated torque, rotation of the cutterhead of approximately $0.4-0.7 \mathrm{rpm}$, and a shield advance rate of approximately $30-70 \mathrm{~mm} / \mathrm{min}$. While the active earth pressure balance was created at cutting face, the simultaneous backfilling of approximately 14.1$15.3 \mathrm{~m}^{3}$ per ring was exerted using the formulation from the field tests. The maximum ground surface settlements were well controlled within $10-40 \mathrm{~mm}$, as shown in Fig. 17. The soils at the tunnel roof have a large influence on the surface settlement. When sand soils were encountered, the larger settlements of 20-40 mm were induced, as shown in Fig. 17c; when clay soils were encountered at the tunnel roof, the settlements were approximately 10-25 mm, as shown in Fig. 17b. As shown in Fig. 17a, most maximum surface settlements were $15.1-30 \mathrm{~mm}$, accounting for $83.87 \%$ of the total. The percentage for each ground condition represents the distribution of the maximum surface settlement, which was the results of the shield tunneling operation (including the simultaneous backfilling grouting). A settlement of $40 \mathrm{~mm}$ was acceptable if no visible damages was done to the surroundings and structures. Surface settlements are also affected by many other factors, such as tunnel depth, shield operation parameters, injection pressure and volume (Banbendererde 1991; Bezuijen et al. 2004; Merritt and Mair 2008; Guo 2013).

As for buildings, houses, pipelines, main road and bridges in the vicinity, shield tunneling induced movements were strictly controlled below the predefined allowable movements with the auxiliary measures taken, such as grouting from the ground surface when necessary. Taking the shield under-crossing the viaduct of the Beijing Airport Express as an example (Guo and Li 2014), three dimensional numerical calculations were performed to predict the movements caused by the shield tunneling using the finite element method in advance. Based on the calculations, anchor-piles were used to reinforce the ground before shield under-crossing. During the under-crossing, strict control of the shield operation was executed, and the maximum settlement of the 
Table 13 The results of the tests of mixing the A-liquids and B-liquids

\begin{tabular}{|c|c|c|c|c|c|c|}
\hline \multicolumn{4}{|c|}{ Mix ratio in mass of the $A$-liquid } & \multirow{2}{*}{$\begin{array}{l}\text { Density } \\
\text { of } A- \\
\text { liquid } \\
\left(\mathrm{g} / \mathrm{cm}^{3}\right)\end{array}$} & \multirow{2}{*}{$\begin{array}{l}\text { Mix ratio } \\
\text { in } \\
\text { volume } \\
\text { of the } \\
\text { A-liquid } \\
\text { to the } \\
\text { B-liquid }\end{array}$} & \multirow{2}{*}{$\begin{array}{l}\text { Final set- } \\
\text { ting time } \\
\text { (s) }\end{array}$} \\
\hline Water & Cement & Slurry & Retarder & & & \\
\hline 0.8 & 1 & 0.3 & 0.013 & 1.31 & $10: 1$ & 20.5 \\
\hline 1.1 & 1 & 0.22 & 0.009 & 1.29 & $10: 1$ & 20.2 \\
\hline 1.1 & 1 & 0.23 & 0.013 & 1.32 & $10: 1$ & 23.5 \\
\hline 1.1 & 1 & 0.33 & 0.011 & 1.27 & $10: 1$ & 35.2 \\
\hline 1.25 & 1 & 0.25 & 0.010 & 1.24 & $10: 1$ & 36.3 \\
\hline 1 & 1 & 0.25 & 0.013 & 1.32 & $10: 1$ & 16.5 \\
\hline 1 & 1 & 0.3 & 0.013 & 1.32 & $10: 1$ & 16.4 \\
\hline 1 & 1 & 0.4 & 0.013 & 1.32 & $10: 1$ & 17.3 \\
\hline 1 & 1 & 0.5 & 0.013 & 1.32 & $10: 1$ & 25.9 \\
\hline 1 & 1 & 0.6 & 0.013 & 1.32 & $10: 1$ & 35.2 \\
\hline 1 & 1 & 3.52 & 0.016 & 1.21 & $10: 1$ & 24.6 \\
\hline 1 & 1 & 3.52 & 0.016 & 1.21 & $11: 1$ & 25.6 \\
\hline 1 & 1 & 3.52 & 0.016 & 1.21 & $12: 1$ & 28.7 \\
\hline 1 & 1.2 & 3.52 & 0.016 & 1.22 & $12: 1$ & 14.7 \\
\hline 1 & 1.4 & 3.52 & 0.016 & 1.23 & $12: 1$ & 13.5 \\
\hline 1 & 1.08 & 0.37 & 0.012 & 1.32 & $10: 1$ & 17.1 \\
\hline
\end{tabular}

viaduct was $<2 \mathrm{~mm}$ of the predefined allowable settlement. The settlement of $2 \mathrm{~mm}$ was required by the owner of Beijing Airport Express. Linear motor-driven trains were adopted on the Beijing Airport Express, which are sensitive to the settlement of the viaduct structure. To guarantee safety of the trains operation, the strict control criterion of $2 \mathrm{~mm}$ was required.

\section{Conclusions}

Based on the application of the $10.22 \mathrm{~m}$ diameter EPB shield with a spoke-type cutterhead in Beijing subway construction, the following conclusions can be drawn:

1. Fluidity of the excavated soils, which are crucial to the creation of the earth pressure balance at the cut-

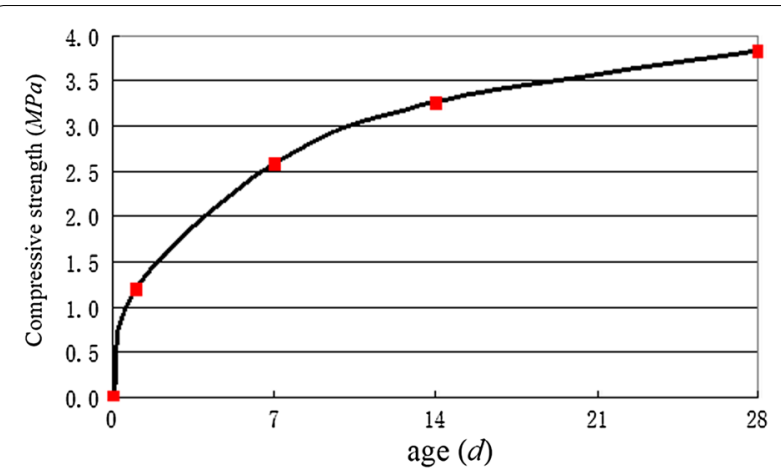

Fig. 16 Variations with age of the compressive strength of the grout test block

ting face, can be achieved through two aspects of work. At first, using suitable additives is the key to condition the soils. The second aspect involves the full mixing of the additives and the excavated soils. For a shield more than $10 \mathrm{~m}$ in diameter, the second work is more important. The construction practice shows that the scheme of injecting the bentonite slurry ( $8 \%$ of Concn) and the foam liquid (5\% of Concn) simultaneously to condition the excavated soils, the special designs of the $10.22 \mathrm{~m}$ diameter shield machine for the agitating system, the simultaneous backfilling grouting system and the independently driven agitating device are successful, and they can provide a useful reference for similar projects.

2. It is feasible for this shield of more than $10 \mathrm{~m}$ in diameter that slumps of the conditioned soils are controlled to approximately $160 \mathrm{~mm}$. When a large cross section of sand or complex surface surroundings are encountered, more foam is required, and the injection ratio of the foam liquid should be increased.

3. The two-component system injection with the adopted mixing ratio of grout determined by the combination of indoor tests and field tests is reasonable for this diameter shield tunneling, resulting in maximum surface settlements of $15-40 \mathrm{~mm}$.
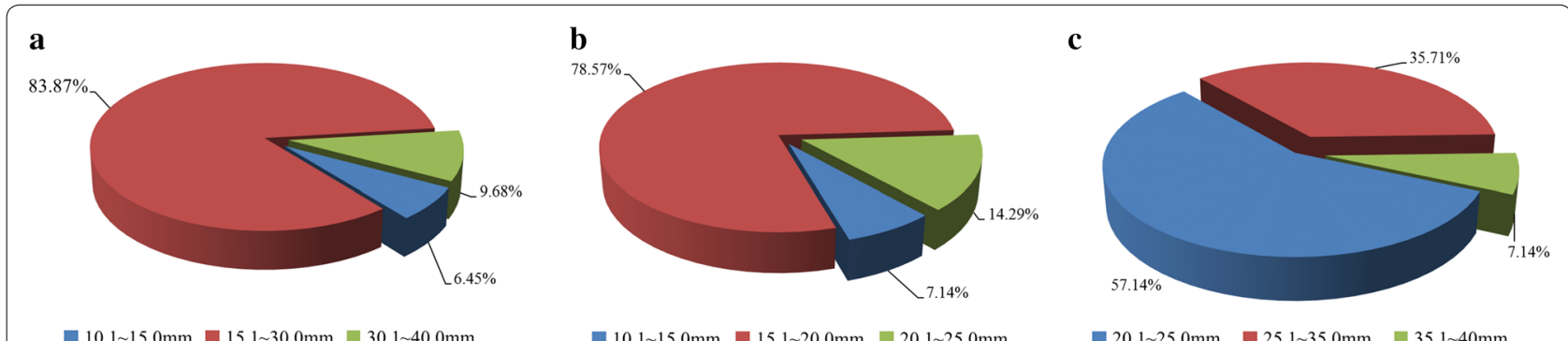

$\square 10.1 \sim 15.0 \mathrm{~mm} \square 15.1 \sim 30.0 \mathrm{~mm} \square 30.1 \sim 40.0 \mathrm{~mm}$

$\square=10.1 \sim 15.0 \mathrm{~mm} \square 15.1 \sim 20.0 \mathrm{~mm} \square 20.1 \sim 25.0 \mathrm{~mm}$

$\square 20.1 \sim 25.0 \mathrm{~mm} \quad \square 25.1 \sim 35.0 \mathrm{~mm} \quad \square 35.1 \sim 40 \mathrm{~mm}$

Fig. 17 Measured maximum surface settlements. a All settlements, b clay soils at tunnel roof, c sandy soils at tunnel roof 


\section{Abbreviations}

EPB: earth pressure balance; Concn: concentration; BIR: bentonite injection ratio; FIR: foam injection ratios; FER: foam expansion ratios; SG: specific gravity; IST: initial setting time; TP: total price.

\section{Authors' contributions}

$X G L$ and DJY designed the research. XGL, YHG and ZYC performed the analysis and wrote the paper. All authors read and approved the final manuscript.

\section{Author details}

1 School of Civil Engineering, Beijing Jiaotong University, Beijing 100044

China. ${ }^{2}$ Beijing Municipal Construction Co., Ltd., Beijing, China.

\section{Acknowledgements}

The authors gratefully acknowledge the financial support by the National Basic Research Program of China under Grant 2015CB057802.

\section{Competing interests}

The authors declare that they have no competing interests.

Received: 25 May 2016 Accepted: 10 November 2016

Published online: 24 November 2016

\section{References}

Al-Sabagh AM, Ahmed Nehal S, Nassar Amal M, Gabr MM (2003) Synthesis and evaluation of some polymeric surfactants for treating crude oil emulsions: part I: treatment of sandy soil polluted with crude oil by monomeric and polymeric surfactants. Colloids Surf A 216(1-3):9-19 Banbendererde S (1991) Tunnelling machines in soft ground: a comparison of slurry and EPB shield systems. Tunn Undergr Space Technol 6(2):169-174
Bezuijen A, Talmon AM, Kaalberg FJ, Plugge R (2004) Field measurements of grout pressures during tunnelling of the Sophia rail tunnel. Soils Found 44(1):39-48

Guglielmetti V, Grasso P, Mahtab A, Xu S (2008) Mechanized tunnelling in urban areas: design methodology and construction control. Taylor \& Francis Group, London

Guo Y (2013) Study on ground surface movement induced by large-diameter earth pressure balance shield tunneling. China Civ Eng J 46(11):128-137 (in Chinese)

Guo YH, Li XG (2014) Safety control technology on large diameter shield under-crossing the viaduct of Beijing airport express. J Beijing Jiaotong Univ 38(1):13-19 (in Chinese)

Liu J, Wang F, He S, Wang E, Zhou H (2015) Enlarge a large-diameter shield tunnel using the Pile-Beam-Arch method to create a metro station. Tunn Undergr Space Technol 49(6):130-143

Maidl B, Herrenknecht M, Maidl U, Wehrmeyer G (2012) Mechanised shield tunnelling, 2nd edn. Ernst \& Sohn, Berlin

Merritt AS, Mair RJ (2008) Mechanics of tunnelling machine screw conveyors: a theoretical model. Géotechnique 58(2):79-94

Peila D, Borio L, Pelizza S (2011) The behaviour of a two-component back-filling grout used in a tunnel-boring machine. Acta Geotech Slov 8(1):5-15

\section{Submit your manuscript to a SpringerOpen ${ }^{\circ}$ journal and benefit from:}

- Convenient online submission

- Rigorous peer review

- Immediate publication on acceptance

- Open access: articles freely available online

- High visibility within the field

- Retaining the copyright to your article 